\title{
2012 年度日本神経学会近畿地区生涯教育講演会抄録
}

\author{
日 時：2013 年 2 月 11 日（月・祝） \\ 会 場：京都教育文化センター 北館 2 階ホール
}

\section{ALS における分子標的治療開発の試み}

\section{伊東 秀文（和歌山県立医大神経内科学講座）}

筋萎縮性側索硬化症(ALS) は原因不明の難病であり、有効 な治療法は確立されていない。現在唯一臨床応用されている リルゾールは、グルタミン酸による興奮性神経毒性仮説に基 ついて開発されたが、満足できる治療効果は得られていない。 ALS の進行を止めるためには、ALS における細胞死の分子メ カニズムを明らかにし、そのプロセスに介入して細胞死を抑 制する分子標的治療の開発が必要である。パーキンソン病で は、家族性パーキンソン病の原因遺伝子が複数発見されたこ とにより、それぞれの遺伝子産物の生理機能や変異タンパク の機能障害が丹念に解析され、ドパミン神経細胞死のメカニ ズムが解明されようとしている。ALS においては、家族性 ALS の原因遺伝子としてまずSOD1が 1993 年に発見されて いたが、2008 年の TDP-43 の発見以降急速に加速し、FUS, optineurin (OPTN), VCP, ubiquilin 2, C9orf72 な゙が相次い で報告されている。現在はこれらの患者の臨床・病理学的解 析や、原因遺伝子産物の機能解析が精力的に進められており、 運動神経細胞死におけるそれぞれの役割が研究されている。

これらのうち、OPTN はTDP-43 陽性封入体・SOD1 陽性 封入体・FUS 陽性好塩基性封入体のいずれにも共存しており、 すべての ALS の発症に関与している可能性が示唆されてい る。OPTN は NF- $\kappa$ B 抑制作用、Golgi 装置維持作用、逆行 性軸索輸送などに関与しており、OPTN 変異により $\mathrm{NF}-\kappa \mathrm{B}$
の活性克進、Golgi 断片化、軸索輸送障害などが生じるが、 これらの所見はこれまで ALS において報告されてきたもの であり、OPTN 機能障害で説明できる可能性がある。現在、 $\mathrm{NF}$ - $\kappa \mathrm{B}$ を分子標的とした治療薬の開発が試みられている。

一方、ALS 患者から樹立した疾患特異的 iPS 細胞を運動二 ユーロンに分化させ、その変性過程を明らかにして新たな治 療薬の開発をめざす試みもなされている。TDP-43 は正常で は核内に存在するが、ALS では核から脱失し、細胞質内に凝 集体を形成する。ALS 患者の iPS 細胞由来運動ニューロンを 観察すると、TDP-43 は核から脱失する前に核内で凝集する ことが明らかになった。TDP-43 の核内凝集に関与する酵素 を標的とし、それを抑制することによって細胞変性を止める 薬物の開発が進められている。

ALS の神経細胞内には異常タンパクが分解されずに蓄積 しているため、タンパク分解系の異常が関与している可能性 が示唆されていたが、最近、ユビキチン・プロテアソーム系 とオートファジー・リソソーム系をそれぞれ運動神経で特異 的にノックアウトしたマウスが作製された。これらのマウス を詳細に検討すると、コビキチン・プロテアソーム系をノッ クアウトしたマウスがヒト ALS と類似の臨床病理所見を呈 したことから、プロテアソームを標的とし、その活性化によ り ALS が治療できる可能性が示唆されている。 
神経変性疾患研究の新しい展開〜タンパク質凝集とエピジェネティクス

岩田淳（東大医学部附属病院, 分子脳病態科学, 神経内科)

神経変性疾患の病理学的特徵としてユビキチン陽性の構 造物の出現がある.これらの構造物を構成する主要なタンパ ク質は構造物毎に異なるが, それぞれが生化学的には不溶性 画分に認められることから, 高次構造の変化を生じて凝集し た状態となっている事が想定される. モデル動物を使用した 過去の研究よりこれら凝集タンパク質の除去は症状の改善 をもたらすため, その除去メカニズムの詳細を明らかにする ことは神経変性疾患の治療実現のためには重要である.

まず細胞内からの封入体除去のメカニズムを考える.封入 体は直径数マイクロメートルある構造物だが, 先行研究から はそれらすら細胞自らの働きで除去されうることが示され ている. 細胞内のタンパク質分解機構の一つユビキチン・プ ロテアソーム(UPS)系では, プロテアソームの内径が $0.1 \mathrm{~nm}$ 程度である事より, 分解されるべきタンパク質はそれよりも 小さい事が要求される. このため, 封入体を直接 UPS で処 理することは不可能である.オートファジーは細胞質タンパ ク質をライソゾームへと送り, 分解するシステムである. 我々はこの系の特異的阻害を行う事でオートファジーが封 入体の分解を行っている事を示した. また, オートファジー
は本来非特異的に細胞質タンパク質を分解する系であるが, 凝集タンパク質の分解においては, 微小管及びモータータン パク質の働きによってオートファジー実行分子と凝集タン パク質の空間的濃縮を実現し, 分解効率を高めていることも 想定された. 封入体は細胞核内にも認められ, 神経毒性は核 内の凝集タンパク質の方が高い事が想定されるが, オートフ アジーは細胞核内では機能せず，細胞核内ではUPS のみが 機能して凝集タンパク質の分解を実行している.

一方で, 孤発性神経変性疾患の病態に眼を向けると, アル ツハイマー病における amyloid $\beta$ やパーキンソン病の $\alpha$ -synuclein のように孤発例で凝集タンパクとして蓄積し, ご く稀な家族性症例でみられる変異がその凝集を促進すると いう事例が多く認められる.これらの家族性と孤発性をつな ぐ現象としてエピゲノム異常を想定した.パーキンソン病の

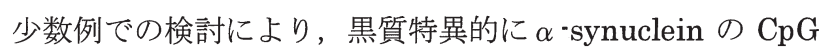
アイランドの一つに極端な脱メチル化が認められ,この脱メ チル化は下流遺伝子発現を上昇させることが判明した.この ため, 孤発例における発症機構の一つとしてエピゲノム異常 が想定される.

遺伝性筋疾患のトピックスと分子標的治療

\section{戸田 達史（神戸大神経内科）}

デュシェンヌ型筋ジストロフィーの原因遺伝子として ジストロフィンが発見されて以来、この 20 年間で、40 種 以上の筋ジス原因遺伝子が報告されている。我が国 において、デュシェンヌ型に次いで多い小児期筋ジスで ある福山型先天性筋ジストロフィー(FCMD) は、先天 性筋ジストロフィーに多小脳回などの脳奇形を伴う常 染色体性劣性遺伝疾患であり、我々の 90 人に1人が 保因者である。1960 年に福山幸夫博士によって発見 され、その約 40 年後の 1998 年に、我々によって、原因 遺伝子フクチンが同定された。

福山型は、muscle-eye-brain 病(MEB)などと類似疾 患とされる。我々は遠藤玉夫博士らとともに糖転移酵 素 POMGnT1 の遺伝子が MEB 原因遺伝子であること を明らかにした。FCMDや やMEB、

Walker-Warburg(WWS)症候群、肢帯型 2I 型などに共 通した病態として、 $\alpha$ ジストログリカンの糖 鎖修飾 異常

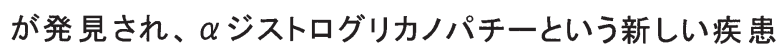

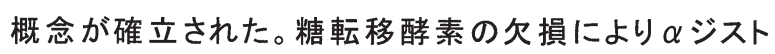
ログリカンの糖 鎖修 飾が乱れ、ラミニンなどとの結 合が できなくなり、脳奇 形を伴う筋ジストロフィーが発症して
いると考えられている。

さらに最近、福山型筋ジストロフィーの根本的治療法 につながる分子メカニズムと治療法を発見した。殆どの FCMD 患者は、フクチン遺伝子の 3' 非翻訳領域に約 $3 \mathrm{~kb}$ の SVA 型レトロトランスポゾンの挿入変異を持つ。 我々は、FCMD が SVA の挿入により誘導される「スプラ イシング異常症」であることを見いだした。さらに異常ス プライシングを阻止するため、スプライシング配列を標 的とするアンチセンス核酸を設計し、患者由来細胞に 導入、及びFCMD モデルマウスに筋注ならびに全身投 与した結果、患者由来細胞において正常のフクチンが 回復し、またモデルマウスにおいて正常フクチンの回 復、 $\alpha$ ジストログリカンの糖 鎖修 飾 及びラミニン結 合能の 回復が確認された。SVA のエクソントラッピング機能は ヒトの疾患や進化に関与しており、FCMDに対しては初 の根治療法実現の可能性が示唆される (エクソントラッ プ阻害療法)。

本教育講演では、最近の筋ジストロフィーの臨床、遺 伝子、病態、分子標的治療などを概観する。 


\section{パーキンンン病の画像診断}

福山 秀直 (京都大脳機能総合研究センター)

パーキンソン病とその類似疾患に関して、最近の進歩をふまえ、 ドパミン代謝とドパミン受容体の臨床的有用性について、以下 の点をまとめて解説した。

1.ドパミンがシナプス間隙から再吸収される機構は、コカイン が作用してドパミンを增加させるものであるが、このような薬 理作用をもたず再吸収部位に結合するコカイン類似物質が多く 見いだされ、それを用いてヨード 123 など SPECT で画像化で きるI123-FP-CIT などが実際の臨木用いることができるように なりつつある。パーキンソン病では、障害部位が基底核の後部 から前方に拡大していく。結合部位からも推測できるように、

ドパミン神経終末の再吸収部位を画像化し、ドパミン神経の機 能を鋭敏に反映する。これは、PET のトレーサーである F-18DOPA と比べると、FDOPA がグリアなどでも代謝されて 正確なドパミン神経終末を表示しないことと比較して、臨床的 に有用な点である。これまで、神経内科医が臨床の 4 兆候をも とにパーキンソン病と診断していたことへの強力な補助診断法 となる。残念ながら、ドパミン受容体（1、2) などは、まだ、 PETによるトレーサーしか使えない状況なので、受容体は正常 でドパミン神経終末が変成しているというパーキンソン病の診 断を下すまでには至らず、パーキンソン症候群としか診断でき ない。今後の重要な課題である。
2.アミロドイメージング。C-11 PiB によって比較的容易にアミ ロイドの沈着を䛦断できるようになり、ほかにも、F-18 PiBや $\mathrm{AV}-45$ などフッ素製剤が米国の FDA で認可されており、今後、 日本でも利用されることになると思われる。

3.アミロイドイメージングに関係して、レビー小体病の診断が、 困難が場合、パーキンソン症候群の根拠があれば、アルツハイ マ一病か、否かが明白になるので、今後、有用性が高くなる。 精神症状を主体としたレビー小体病は、パーキンソン症状がは つきりしないことが少なくない。これまで、レビー小体病と診 断されたものをみると、アルツハイマー病では FP-CIT などで の基底核のドパミン神経終末の障害は見られず、レビー小体病 では、はっきりと基底核後部のドパミン神経終末へのアイソト 一プの沈着が減少して、鑑別診断にきわめて有効である。ただ、 パーキンソン病を 10 年以上経過観察していると、認知症が 徐々に見られるが、このような症例がどの程度アミロイドの関 与があるか、現在まだ明確ではなく、むしろ、 $\alpha$ シヌクレイン による大脳皮質神経障害も考えられている。 